\title{
A Study of Basic Military Training on the Physical Fitness and Physical Self-Concept for Cadets 入伍訓練對軍校新生體適能及自我身體概念的研究
}

\author{
Kenny Wen-Chyuan CHEN ${ }^{1}$ Pin-Kun CHIU ${ }^{2}$ I-An LIN $^{3}$

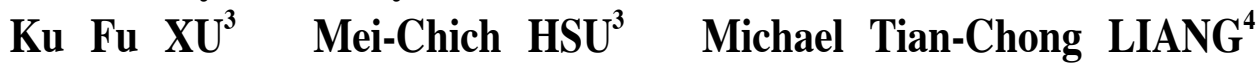 \\ ${ }^{1}$ General Education Center, Chang Gung Institute of Technology, TAIWAN \\ ${ }^{2}$ Graduate Institute of Sports Training Science, \\ National College of Physical Education and Sports, TAIWAN \\ ${ }^{3}$ Graduate Institute of Sports Science, \\ National College of Physical Education and Sports, TAIWAN \\ ${ }^{4}$ Department of Kinesiology and Health Promotion, \\ California State Polytechnic University, California USA
}

\section{1 陳文詮 ${ }^{2}$ 邱炳坤 ${ }^{3}$ 林益安 \\ 3 徐谷甫 3 許美智 4 龍田種 \\ 1. 台灣長庚技術學院通識敎育中心 \\ 2. 台灣國立體育學院運動技術研究所 \\ 3. 台灣國立體育學院運動科學研究所 \\ 4. 美國加州理工大學人體運動暨健康促進學系}

\begin{abstract}
This study investigated the physiological and psychological aspects of first-year cadets who adopted a basic military training. We focused on the extent to which the Military physical fitness and the physical self-concept will be affected by a basic military training program. Military physical fitness included the score of BMI, pull-ups, 3000m endurance running and 1-min sit-up. Physical self-concept was assessed using the Marsh's Physical Self-Description Questionnaire (PSDQ), which was adapted to use in college students. PSDQ scale was assessed using a 6-point rating scale on which the subject estimated their physical characteristics. Testing was administered in a pre- and posttest fashion over 9 weeks $(n=166)$. The collected data were analyzed by t-test. The study revealed that 1) Military physical fitness that including 3000m endurance running, 1-min sit-up and BMI are significant $(\mathrm{p}<.05)$, (2) total score of PSDQ assessment are non-significant ( $\mathrm{p}>.05)$, (3) the health of PSDQ are significant $(\mathrm{p}<.05)$, (4) the physical activity of PSDQ are significant ( $<<.05)$. Results show that physical fitness and psychological measurement are really affected by basic military training program such that cadets have a more positive health and better body conditions due to basic military training.
\end{abstract}

Key words: cadet, physical self-concept, physical fitness, basic military training

\section{摘 要}

本研究的主要目的在於研究軍校新生在經過入伍訓練後其生理與心理方面的變化。我們研究主要焦點在於入伍訓練課程能 否影響軍方體適能和身體自我概念, 而軍中體適能的項目包含 : 拉單梖、 3000 公尺耐力跑、一分鐘仰卧起坐, 身體自我概念的 評估則是將Marsh的身體自我描述問卷(PSDQ)改編成適合大專學生適用的量表。PSDQ 的評估使用六點等級讓受試者來評估自 己的身體特點。 測試分別在9周入伍訓練的前後實施(共166人)。收集到的資料以成對樣本 T考驗檢定。本研究的結果呈現(1)軍 
方體適能中的 3000 公尺耐力跑, 一分鐘仰臥起坐和BMI皆有顯著的變化(p<.05) (2) PSDQ 的總得分並未變化(p>.05) (3) PSDQ 的健康分項得分有顯著差異( $\mathrm{p}<.05$ ) (4) PSDQ 的身體活動分項得分有顯著差異 $(\mathrm{p}<.05) \circ$ 。結果顯示體適能和心理方面的 測量確實受到入伍訓練的影響, 所以軍校生會因為入伍訓練而有更積極正向的健康概念與較佳的身體狀沉。

關鍵字：軍校生，身體自我概念，體適能，入伍訓練

\section{Introduction}

Physical fitness is the ability of a person to function efficiently and effectively, to enjoy leisure, to be healthy, to resist hypokinetic disease, and to cope with emergency situations. Physical fitness and physical self-concept have interactions. On self-concept, there are many instruments to measure it. But, Sports and exercise psychologists have argued that the recycling psychological measurements are not sport specific (e.g. Corbin, 1991; Gill, Dzewaltowski \& Deeter, 1988; Marsh \& Redmayne, 1994; Sonstroem, Speliotis \& Fava, 1992; Vealey, 1986). So, a number of physical self-concept measurements have been developed to specific domains of physical self-concept or to global components of physical self-concept and self-esteem. These instruments are vary degrees base on the Marsh/ Shavelson multidimensional, hierarchical model of selfconcept and self-concept derived from these models, such as the Self-Description Questionnaire (SDQ) (Marsh, 1994).

Johnson (1970) used the Tennessee Self concept scale to make a comparison of physical fitness and self-concept between junior high Negro and white male students $(n=135)$. He found that Negro students have higher score than white students on physical self-worth, health, appearance and motor skill. Denby (1979) also found that self-concept score was not affected by the results of basketball game, but the school basketball teammates have higher selfconcept score than the other participants.

Wilfley \& Kunce (1986) found 8 weeks exercise program can increase subject's endurance and self-concept, but decreased subject's mood tension. Woelke (1987) found that children who participate sports have higher perceived competence than the non-participants. For realizing the effects of physical activity on participant's self-perception, Fox \& Corbin (1989) developed a physical self-perception profile (PSPP). PSPP based on a self-perceived model which consistent with a three-tier hierarchical structure. Bodily attractiveness, sports competence, physical strength, and physical conditioning were constructed with a general physical self-worth subscale of the PSPP, and the selfesteem was a top tier. Exploratory and confirmatory factor analyses indicate the discriminative validity of the subdomain subscales and support the concept of multidimensionality within the physical domain.

Sonstroem, Speliotis and Fava (1992) assessed the structure and validity of the PSPP when used with adults in their middle and later years. Principal-component analyses revealed overlap scales between physical selfworth and attractive body. Studying PSPP scales are strongly encouraged.

Salokun (1990) investigated the effects of basketball and field-hockey training on the self-concepts of 12-14 and 16-18 years old secondary school males and females. The results showed that the skill training and ability in sports tend to influence the development of positive selfconcept. Finkenberg (1990) found that the college women who participated the Taekwondo have higher total selfconcept scores than who participated general physical education.

Marsh \& Peart (1988) examined the differential effects of a competitive and a cooperative fitness program for high school girls on physical fitness and on multidimensional self-concepts, they found that physical fitness is significantly correlated with self-concept of physical ability and both the competitive and the cooperative programs significantly enhance physical fitness. However, the cooperative program also enhances physical ability self-concept but a lesser degree of physical appearance self-concept, whereas the competitive program lowers both aspects of self-concept. Marsh \& Redmayne (1994) examined relations between six components of physical self concept (Endurance, Balance, Flexibility, Strength, Appearance, and general Physical Ability) and five components of physical fitness (Endurance, Balance, Flexibility, Static Strength, Explosive Strength/Power) for a sample $(\mathrm{N}=105)$ of young adolescent girls aged 13 and 14. Hierarchical confirmatory factor analyses identified the six physical self-concept scales and provided support for a multidimensional and hierarchical model of physical selfconcept. The patterns of correlation between the specific components of physical self-concept and the physical 
fitness generally supported the construct validity of the self-concept responses and the correlation between secondorder factors, indicated that the correlation between the general physical self-concept and the general physical fitness $(\mathrm{r}=.76)$ was substantial.

Marsh, Richards, Johnson, Roche \& Tremayne (1994) used confirmatory factor analyses for PSDQ to demonstrate support for the 11 scales of physical self-concept (Strength, Body Fat, Activity, Endurance/Fitness, Sport Competence, Coordination, Health, Appearance, Flexibility, General Physical Self-Concept, and Self-Esteem). They recommended the PSDQ is in a wide variety of research and applied settings.

Basic military training is a very important training to cadet, especially for the first- year cadet of military college. Many sports psychologist indicated that most of the people who have better physical fitness would have higher physical self-concept. In Lin's (2001) study, soldiers increased their physical fitness level significantly except the flexibility after basic military training. However, no studies proved the relation between basic military training and physical self-concept so far. According to the former studies results-to participate general physical activity can increase participant's physical self-concept. Although basic military training is a special physical activity, we supposed that the first-year cadets would enhance their physical fitness after 9 weeks basic military training, and we thought the cadets should increase their physical selfconcept also.

\section{Methods}

\section{Subjects}

Subjects for this study were first-year male cadets $(n=166$, mean age $=18.2)$ who were all selected from the National Defense College of Management in Taiwan. Prior to participation, informed consent was obtained from the subjects.

\section{Experimental Design}

To test the effects of Basic Military Training on relevant dependent variables, a typical research testing design including before and after an intervention period was used. All participants were instructed not to alter their normal physical activities during participation in this study.

\section{Testing Procedures}

Testing was administered to participants in a preand posttest fashion over nine weeks basic military training, including physical fitness tests and a physical self-description questionnaire. The physical fitness were used to present the body composition defined by Body Mass Index (BMI), arm endurance defined by the pull ups of 1-miniute, cardiovascular function measured the 3000 meters of the time it took to run, and total body muscle endurance measured the 1-minute of sit ups done.

The Questionnaire used was the modified Physical Self-Description Questionnaire for Chinese College students by $\mathrm{Ye}(1998)$. This Questionnaire includes 54 item to measure nine specific components: Appearance (being good looking, having a nice face); Strength (being strong, having a powerful body with lots of muscles); Endurance (being able to run a long way without stopping, not tiring easily when exercising hard) ; Flexibility (being able to bend and turn your body easily in different direction) ; Health (not getting sick often, getting well quickly when you are sick) ; Sports Competence (being good at coordinated movements, being able to do physical movements smooth, being good at sports, being athletic, having good sports skills) ; Body fat not being overweight, not being too fat); Physical activity (being physical active, doing lots of physical activities regularly) ; and Self-esteem (viewing oneself as a competent and worthy person) . Each PSDQ item is a simple declarative statement, and participates respond using a 6-point scale true-false response scale.

\section{Basic Military Training}

BMT for cadets are structured in the areas of organized group physical training and conditioning. The Taiwan Army cadets training at Feng-Shan, Kaohsiung, conducted BMT in a 9-week course under the direction of drill instructors using standardized guidelines for the conduct of physical training. Cadets were organized into training companies (four platoons per company) where daily routine training drills and skills were executed. Formal physical training included warm-up and cool-down exercises, sit-ups, and pushups, and unit (group) 2000 meters running every morning. Informal physical training, conducted under the direction of the drill instructors about 2 to 4 days per week included activities chosen from an option list (e.g., grass drills, guerilla exercises, poleclimbing, circuit course drills, single and parallel bars, and partner resisted exercises). 


\section{Statistical Analysis}

Values are reported as means \pm standard deviations error mean (SE). A paired t-test statistical procedure of 10.0 SPSS was used to determine the difference in the subscales of physical self-concept and physical fitness before and after the Basic Military Training.

\section{Results}

Table 1 shows the change of cadet's physical fitness after the nine weeks basic military training. BMI and 3000 meter running were significantly better than before $(t=2.50$, $\mathrm{p}<.05 ; \mathrm{t}=-5.23, \mathrm{p}<.05)$. But 1 -min sit-ups was significantly lower than before $(\mathrm{t}=0.69, \mathrm{p}<.05)$. In addition, 1-min pullup was no significance.

Table 1. Results for the Body Mass Index(BMI), 3000 meters Running, One-minute, Sit-up and One-minute Pull-up Tests for the Pre-Training and Post-Training Testing Occasions (Means \pm SD)

\begin{tabular}{lllllll}
\hline Physical Fitness & Before & \multicolumn{1}{l}{ After } & t- value & p- value \\
B.M.I. $\left(\mathrm{m} / \mathrm{kg}^{2}\right)$ & $\mathrm{M}$ & $\mathrm{SD}$ & $\mathrm{M}$ & $\mathrm{SD}$ & & \\
3000M running & 21.8 & \pm 2.5 & $22.0 \pm \pm 2.4$ & $-2.50^{*}$ & .01 \\
1-min sit-ups & $902.1 \pm 123.3$ & $871.7 \pm 108.4$ & $5.23^{*}$ & .00 \\
1-min pull-up & 42.6 & \pm 6.8 & $42.5 \pm \pm 6.7$ & $0.69^{*}$ & .49 \\
\hline
\end{tabular}

*Denotes statistical significance from the pre-training $(\mathrm{p}<0.05)$.

Table 2 shows the change of cadet's physical selfconcept score after nine weeks B.M.T. The Health scores were significantly higher $(\mathrm{p}<.05)$ than before, but Appearance and Self-esteem were non-significant ( $\mathrm{p}>05$ ).
The Physical activity scores were significantly higher $(t=2.07$, $\mathrm{p}<.05)$ than before, but Total scores, Sports competence scores, Body fat scores, Flexibility scores, Endurance scores and Strength scores were non-significant ( $p>05$ ).

Table 2. Results for the Sports Competence, Appearance, Body Fat, Health, Flexibility, Physical activity, Self-esteem, Endurance, Strength and Total Score Questionnaire Tests for the Pre-training and Post-Training Testing Occasions (Means \pm SD)

\begin{tabular}{|c|c|c|c|c|}
\hline Physical self-concept & Before & After & t- value & p- value \\
\hline & $\mathrm{M} \quad \mathrm{SD}$ & SD & & \\
\hline Sports competence & $24.2 \pm 6.6$ & $23.4 \pm 6.9$ & 1.49 & .14 \\
\hline Appearance & $27.3 \pm 6.8$ & $28.1 \pm 6.1$ & -1.84 & .07 \\
\hline Body fat & $17.2 \pm 8.1$ & $16.4 \pm 8.0$ & 1.76 & .08 \\
\hline Health & $27.3 \pm 4.3$ & $28.3 \pm 4.2$ & $3.27 *$ & .00 \\
\hline Flexibility & $16.9 \pm 4.8$ & $16.6 \pm 4.8$ & 0.74 & .46 \\
\hline Physical activity & $19.6 \pm 6.2$ & $18.3 \pm 5.6$ & $2.07 *$ & .04 \\
\hline Self-esteem & $19.9 \pm 3.2$ & $20.0 \pm 2.7$ & -0.58 & .56 \\
\hline Endurance & $17.2 \pm 5.8$ & $16.5 \pm 6.3$ & 1.35 & .18 \\
\hline Strength & $13.3 \pm 3.7$ & $13.1 \pm 3.8$ & 0.71 & .48 \\
\hline Total score & $183.6 \pm 27.8$ & $179.7 \pm 26.6$ & 1.79 & .08 \\
\hline
\end{tabular}

*Denotes statistical significance from the pre-training $(\mathrm{p}<0.05)$. 


\section{Discussion}

The purpose of this study was to investigate the effects of 9 weeks basic military training on cadet's physical fitness and physical self-concept.

\section{Physical Fitness}

After 9 weeks basic military training, cadets made a progress in most items of physical fitness. Cadet's BMI was increased $\left(21.8 \mathrm{~kg} / \mathrm{m}^{2}\right.$ to $\left.22.0 \mathrm{~kg} / \mathrm{m}^{2}, \mathrm{p}<.05\right)$, but BMI was still on the Taiwan's normal range. BMI present the body composition, it has been indicator of obesity on the assumption that the higher BMI, the greater body fat. Chen (2001) indicated that cadet's maintained their BMI between 21.6 to 22.1, but their other physical fitness were enhanced year by year in four college life. Chen thought the increased BMI was resulted from the increased muscle volume. In our study, cadet significantly enhanced the $3000 \mathrm{~m}$ running (902.1 seconds to 871.7 seconds, $\mathrm{p}<.05$ ), it means basic military training can improve cardiovascular function, this results support Chen's result. We suppose that increased BMI was resulted from the increased muscle volume.

In 1-min sit-ups cadet were lower than before (42.6 to $42.5 \mathrm{p}<.05)$. The results were a little different from Lin's study (2001). Lin's research indicated that man on army duty service undergo basic military training, who can be enhanced their physical fitness (muscle strength, muscle endurance, agility and cardiovascular function except flexibility). In our study, the 1-min sit-ups (muscle endurance) was decreased. The purpose of basic military training was different from Lin's, for cadet's basic military training is to rebuild their concept not just on the body condition. There are many indoor classes during the training, and they seldom do the abdominal exercise. So, cadet's muscle endurance was decreased.

\section{Physical Self-concept}

In Marsh etc. (1986a, 1986b) studies, they found that people participated a long-term program can increase their multidimensional self-concept and the effects will be maintained, the others researches also have the same effects. (Miller,1989; Finkenberg,1990; McGowan etc,1974). Some researchers also indicated that people with good body conditions have better physical self-concept (Marsh \& Redmayne, 1994; Wilfley \& Kunce, 1986), and physical fitness was significantly correlated with self- concept of physical ability. (Marsh \& Peart, 1988). Woelke (1987) also found that sport participants' physical self-competence were better than sport non-participants.

In our study, cadets physical fitness were enhanced after the basic military training, but cadets' total physical self-concept scores made no difference between before basic military training and after basic military training. We thought it was a frame of reference effects, Marsh (1998) indicated that self-concept is substantially influenced by frame of reference effects (FRE). How favorably individuals perceive themselves depends not only on their objective accomplishments, but also on how these accomplishment compare with frames of reference established by the expectations and performances of significant others. Military college is a special school which emphasis the physical fitness and tactics. In generally, cadet should pass the physical education exam (including military basic physical fitness) in every semester. Furthermore, the captain would make the cadet to have a long running at morning break and after the classes almost every day. Even if cadet's performance were getting better, their total physical self-concept scores were not increase. This may be result in FRE, because new cadet will elevate their physical fitness standard after the basic military training. The other scholar Hawkins and Gruber (1982) indicated that if coach usually gave bad feedbacks to students, it may lowered student's confidence and self- esteem. So, the training officer can affect cadets by their educational style.

In correlated physical fitness subscale of PSDQ, the physical activity scores, which were significant lower than before (19.6 to $18.3, \mathrm{p}<.05)$. In fact, cadet's workload was higher than before during the basic military training, however our results were not like that. We supposed that could be effects by FRE and training officer's teaching style.

In another subscale of PSDQ, the Health scores were significant increased than before (27.3 to 28.33 , $\mathrm{p}<.05)$. It is perceived that basic military training have a positive effect on non-physical subscale of Physical selfconcept. This result supported the findings of Miller (1989), Finkenberg (1990) and McGowan, Jarman \& Pedersen (1974) that good program can increase their multidimensional self-concept. 


\section{Summary and Implications}

This study was to realize the effect of 9 weeks basic military training in first-grade cadet's physical and psychological aspects. We found basic military training could significant enhance $(\mathrm{p}<.05)$ cadet's BMI, 3000m endurance running (cardiovascular function), but 1-min sit-ups ( total body muscle endurance) were lower. On physical self-concept aspects, the result was unexpectedly. Although cadet's physical fitness were enhanced, but the scores related with physical fitness, the physical activity scores were significant lower (19.57 to $18.31, \mathrm{p}<.05)$ than before. And the Health scores were significant increased than before (27.25 to $28.33, \mathrm{p}<.05)$.

Combining the results with physical fitness and physical self-concept of the cadets, we indicated that basic military training could effectively enhance firstgrade cadet's physical fitness and non-physical subscale of Physical self-concept. However, we suggested that army training center should correct the style of training about the cadets, instead of encouragement to let cadets can accept their physical ability through the basic military training and helped cadets to rebuilt their self-esteem.

\section{Acknowledgement}

We would like to thank the staff and cadets from the Republic of China National Defense Management College for their assistance, and Dr. John Chang's advise for the statistical analyses.

\section{Reference}

Chen, Kenny W. C., Hsu, G. C., Lee, \& Alex J. Y. (2001). The influence of 4yrs army's force academy life for the cadet's physical fitness-for example, the NDMC's student, 2001 International congress of coaching science, 627-645.

Corbin, C. B. (1991) A multidimensional hierarchical model of physical fitness: A basis for integration and collaboration. Quest, 43, 296-306.

Denby, P. A. (1979) Basketball participation and the self concept. University of Oregon Eugene, OR.
Finkenberg, M. E. (1990). Effect of participation in Taekwondo on college women's self-concept. Perceptual and Motor Skills, 71(3), 891-894.

Hawkins, D. B., \& Gruber, J. J. (1982.) Little league baseball and Players' self-esteem. Perceptual and Motor Skills, 55(3), 1335-1340.

Fox, K. R., \& Corbin, C. B. (1989) The Physical SelfPerception Profile: Development and Preliminary Validation. Journal of Sport \& Exercise Psychology, 11, 408-430.

Gill, D. L., Dzewaltowski, D. A., \& Deeter, T. E. (1988) The relationship of competitiveness and achievement orientation to participation on sport and nonsport activities. Journal of Sport \& Exercise Psychology, 10, 139-150.

Johnson, J. B. (1970) A Comparison of Physical Fitness and Self-Concept Between Junior High Negro and White Male Students. s.n. s.l., p 139.

Lin, R. I. (2001). The effects of Basic Military Training on health-related fitness and blood fat, 2001 Army tactics and physical fitness symposium, p127-149.

Marsh, H. W. (1998). Age and gender effects in physical self-concept for adolescent elite athletes and nonathlete: A muilticohort-multioccasion design. Journal of Sport \& Exercise Psychology, 20, 237259.

Marsh, H. W. (1993). Physical fitness self concept: Relations of physical fitness to field and technical indicators for boys and girls aged 9-15. Journal of Sport \& Exercise Psychology, 15, 184-206.

Marsh, H. W. (1994). The importance of being important: Theoretical model of relations between specific and global components of physical self-concept. Journal of Sport \& Exercise Psychology, 16, 306-325.

Marsh, H.W., Richards, G. E.,\& Barnes, J. (1986a). Multidimensional self-concept: The effect of participation in an Outward Bound Program. Journal of Personality and Social Psychology, 50, 195-204. 
Marsh, H.W., Richards, G. E., \& Barnes, J. (1986b). Multidimensional self-concept: A long-term followup of the effect of participation in an Outward Bound Program. Journal of Personality and Social Psychology, Bulletin, 12, 475-492.

Marsh, H. W., \& Peart, N. D. (1988). Competitive and cooperative physical fitness training programs for girls: Effects on physical fitness and multidimensional self- concepts. Journal of Sport \& Exercise Psychology, 10, 390-407.

Marsh, H. W., \& Redmayne, R. S. (1994). A multidimensional physical self-concept and its relations to multiple components of physical fitness. Journal of Sport \& Exercise Psychology, 16, 43-55.

Marsh, H.W. Richards, G.E. Johnson, S. Roche, L., \& Tremayne, P. (1994). Physical Self-Description Questionnaire: psychometric properties and a multitrait-multimethod analysis of relations to existing instruments. Journal of Sport \& Exercise Psychology 16(3), 270-305.

McGowan, R. W., Jarman, B. O., \& Pedersen, D. M. (1974). Effects of a competitive endurance training program on self-concept and peer approval. Journal of Psychology, 86(1), 57-60.

Miller, R. (1989). Effect of sports instruction in children's self-concept. Perceptual and Motor Skills. 68(1), 239242.

Salokun, S. O. (1990). Effects of training in basketball and field-hockey skills on self-concepts of Nigerian adolescents. International Journal of Sport Psychology 21(2), Apr/June, 121-137.

Sonstroem, R. J., Speliotis, E. D., \& Fava, J. L. (1992) Perceived physical competence in adults: An examination of the physical self perception profile. Journal of Sport \& Exercise Psychology, 14, 207221.

Vealey, R. S. (1986). Conceptualization of sport-confidence and competitive orientation: Preliminary investigation and instrument development. Journal of Sport \& Exercise Psychology, 8, 221-246.
Wilfey, D., \& Kunce, J. (1986). Differential physical and psychological effects of exercise. Journal of counseling psychology 33(3), 337-342.

Woelke, D. (1987). Perception of physical self-competence among young male sport participants and sport nonparticipants. Fullerton: California State University.

Ye, S. R. (1998). The study of the relationship between physical self-concept \& sports participation in collegiate students. Unpublished master's thesis, National College of Physical Education and Sports, Taipei.

\section{Correspondence:}

\section{Kenny Wen-Chyuan Chen}

General Education Center, Chang Gung Institute of Technology, Taoyuan County, Taiwan.

261, Wenhua 1st Rd, Gueishan, Taoyuan, Taiwan 333, R.O.C. E-mail: kennycwc@ms18.hinet.net Telephone: 886-3-2118999 ext. 5660

Fax: 886-3-2118866 